\title{
ANALISIS FAKTOR PENENTU PRICE EARNINGS RATIO: STUDI PADA PERUSAHAAN YANG TERDAFTAR DI BURSA EFEK INDONESIA
}

\author{
Maulana Ainul Yaqin ${ }^{1}$,Nur Imamah ${ }^{2}$ \\ Universitas Brawijaya, Malang, Jawa Timur, Indonesia ${ }^{12}$ \\ Corresponding author ${ }^{2}$ \\ Email: nurima_fia@ub.ac.id
}

\begin{abstract}
ABSTRAK
Studi ini mempunyai tujuan untuk mengetahui pengaruh Dividend Payout Ratio, Earnings Growth Ratio, Debt to Asset Ratio, dan Dividend Per Share terhadap Price Earnings Ratio pada perusahaan yang terdaftar Indek LQ45 di pasar modal Indonesia periode 2016-2018. Studi ini adalah termasuk penelitian explanatory. Analisis data yang digunakan yaitu analisis regresi linier berganda dengan pendekatan Ordinary Least Squares (OLS). Hasil penelitian menunjukkan bahwa Dividend Payout Ratio dan Dividend Per Share berpengaruh signifikan terhadap Price Earnings Ratio. Sedangkan, Earnings Growth Ratio dan Debt to Asset Ratio berpengaruh tidak signifikan terhadap Price Earnings Ratio. Selain itu, temuan yang menarik dalam penelitian ini adalah Dividend Payout Ratio merupakan rasio yang paling dominan dalam menentukan Price Earnings Ratio. Hasil penelitian juga menunjukkanbahwa nilai koefisien determinasi $\left(\mathrm{R}^{2}\right)$ adalah sebesar 73,6\%. Ini menjelaskan bahwa rasio-rasio yang digunakan dalam penelitian ini adalah penting untuk menentukan atau mempengaruhi nilai Price Earnings Ratio.
\end{abstract}

Kata Kunci: Dividend Payout, Dividend Per Share, Price Earnings Ratio.

\begin{abstract}
This study aims to determine the effect of the Dividend Payout Ratio, Earnings Growth Ratio, Debt to Asset Ratio, and Dividend Per Share on the Price Earnings Ratio of companies listed on the LQ45 Index in the Indonesian capital market for the 2016-2018 period. This study is an explanatory research. Analysis of the data used is multiple linear regression analysis with Ordinary Least Squares (OLS) approach. The results showed that the Dividend Payout Ratio and Dividend Per Share had a significant effect on the Price Earnings Ratio. Meanwhile, Earnings Growth Ratio and Debt to Asset Ratio have no significant effect on Price Earnings Ratio. In addition, an interesting finding in this study is that the Dividend Payout Ratio is the most dominant ratio in determining the Price Earnings Ratio. The results also show that the coefficient of determination (R2) is $73.6 \%$. This explains that the ratios used in this study are important to determine or influence the value of the Price Earnings Ratio.
\end{abstract}

Keywords: Dividend Payout, Dividend Per Share, Price Earnings Ratio. 


\section{PENDAHULUAN}

Globalisasi adalah fenomena internasional yang terjadi karena adanya pertukaran pemikiran, produk, kebudayaan yang dapat mempengaruhi berbagai aspek negara seperti politik, ekonomi, sosial, teknologi, dan lingkungan. Era globalisasi ditandai dengan semakin majunya peran pasar, investasi, dan bidang ekonomi secara global yang saling berhubungan satu dengan lainnya. Perkembangan globalisasi mendorong perekonomian negara untuk tumbuh lebihcepat sehingga dapat bersaing dengan negara lain.

Salah satu sumber pendanaan eksternal perusahaan berasal dari investasi. Investasi merupakan penundaan konsumsi sekarang untuk dimasukkan ke aktiva produktif selama periode waktu tertentu (Hartono, 2017:5). Investor tentu mengharapkan imbal hasil dengan keuntungan dari investasi yang ditanamkan. Dasar keputusan investasi terdiri dari tingkat return yang diharapkan, tingkat resiko, serta hubungan antara return dan resiko (Tandelilin, 2010:6). Investasi langsung dapat dilakukan dengan membeli aktiva keuangan yang dapat diperjual-belikan di pasar uang (money market), pasar modal (capital market), atau pasar turunan (derivative market).

Salah satu investasi jangka panjang yang menguntungkan adalah investasi saham. Saham didefinisikan sebagai tanda penyertaan modal atau kepemilikan seseorang atau badan dalam suatu perusahaan (Sunariyah, 2000:49). Untuk menarik investor potensial lainnya, suatu perusahaan mungkin juga mengeluarkan jenis lain dari saham, yaitu saham preferen. Saham merupakan salah satu instrumen pasar modal yang digemari oleh para investor, karena saham menawarkan berbagai keuntungan antara lain dividen dan capital gain.

Dividen merupakan pembagian keuntungan yang diberikan oleh perusahaan kepada investor atas saham yang dimiliki, sedangkan capital gain merupakan keuntungan yang didapatkan investor dari selisih harga beli dan harga jual saham yang dimiliki. Saham memberikan return atau keuntungan tinggi tetapi juga memiliki resiko yang tinggi pula seperti tidak mendapatkan deviden, potensi loss dari selisih rugi antara harga jual dan beli, atau perusahaan bangkrut dan menerima hasil pembagian likuidasi terakhir kali. Investor perlu untuk meminimalkan resiko yang akan ditanggung dengan cara melihat dan menganalisis kondisi pasar. Analisis kondisi pasar untuk menilai harga saham perusahaan yang diinginkan investor.

Dua macam analisis yang banyak digunakan untuk menentukan nilai sebenarnya dari saham adalah analisis sekuritas fundamental (fundamental security analysis) atau analisis perusahaan (company analysis) dan analisis teknis (technical analysis) (Hartono, 2017:208). Analisis teknis menggunakan data pasar dari saham seperti harga dan volume transaksi saham untuk menentukan nilai dari saham, sedangkan analisis fundamental menggunakaan data yang berasal dari keuangan perusahaan untuk menentukan nilai dari saham. Analisis fundamental berkaitan dengan kondisi keuangan perusahaan. Dengan analisis fundamental dapat diketahui nilai intrinsik yaitu nilai saham yang sebenarnya atau seharusnya terjadi.

Dalam membeli atau menjual saham, investor akan membandingkan nilai intrinsik dengan nilai pasar saham yang bersangkutan. Nilai pasar adalah nilai saham di pasar, yang ditunjukkan oleh harga saham tersebut di pasar. Ketika harga pasar saham lebih tinggi dari harga intrinsiknya, maka saham tersebut tergolong mahal. Dalam situasi ini sebaiknya investor mengambil keputusan untuk menjual saham tersebut dam begitu sebalikanya. Sehingga investor dalam hal ini dapat mengambil keputusan untuk membeli saham tersebut. Sedangkan apabila harga pasar suatu saham sama dengan harga intrinsiknya, maka saham tersebut dinilai wajar (corectly valued). 
Dalam situasi ini investor sebaiknya menahan saham tersebut.

Salah satu pendekatan populer yang menggunakan nilai earnings untuk mengestimasi nilai intrinsik adalah pendekatan PER (Price Earnings Ratio) atau disebut juga dengan pendekatan earnings multiplier (Hartono, 2017:224). Berdasarkan data Bursa Efek Indonesia (BEI) rata-rata PER Indeks Harga Saham Gabungan (IHSG) nilainya semakin meningkat, seperti dari tahun 20142018, rata-rata PER selalu diatas 20 kali dan hanya pada tahun 2014 PER di bawah 20 kali. Pendekatan PER seringkali digunakan oleh para analisis fundamental dikarenakan rumusnya lebih sederhana dan investor dapat lebih akurat membandingkan nilai dari dua atau lebih perusahaan. PER berfungsi untuk menilai kewajaran harga saham suatu perusahaan.

PER atau Price Earning Ratio atau juga disebut rasio harga terhadap laba bersih per saham merupakan nilai harga suatu saham yang dibagi dengan earnings per share (EPS) atau angka ini menunjukkan sebuah harga suatu saham berapa kali jika dibandingkan dari laba bersih per saham di dalam satu tahun buku. Dengan demikian pertumbuhan EPS memberikan informasi yang lebih banyak kepada investor tentang perkembangan suatu perusahaan. PER digunakan oleh investor sebagai acuan dalam menanamkan modalnya dalam bentuk saham dengan melihat seberapa besar tingkat pertumbuhan perusahaan dalam menghasilkan laba.

Dari penjelasan diatas, studi ini menguji pengaruh Dividend Payout Ratio (DPR), Earnings Growth Ratio (EGR), Debt to Asset Ratio (DAR), dan Dividend Per Share (DPS) terhadap Price Earnings Ratio (PER) pada perusahaan yang terdaftar di Indeks LQ45 Bursa Efek Indonesia periode 2016-2018. Motivasi dilakukan penelitian ini adalah bahwa penelitian ini menggunakan metode analisis regresi linear berganda dengan menggunakan pendekatan ordinary least square (OLS) yang berbeda dengan penelitian sebelumnya dan masih belum banyak dilakukan dengan topik penelitian yang sama di Indonesia. Penelitian ini juga berkontribusi bagi investor sebagai tambahan informasi bagi mereka mengenai analisis fundamental dengan pendekatan Price Earnings Ratio (PER) serta mampu menjadi pertimbangan investor dalam pengambilan keputusan investasi di pasar modal.

\section{KAJIAN PUSTAKA}

\section{Faktor Penentu Price Earnings Ratio}

Menurut Halim (2015:13), menyatakan bahwa investasi pada hakekatnya merupakan penempatan sejumlah dana pada saat inidengan harapan untuk memperoleh keuntungan di masa mendatang. Berbeda dengan pendapat (Hartono, 2017:5), menyatakan bahwa investasi merupakan penundaan konsumsi sekarang untuk dimasukkan ke aktiva produktif selama periode waktu tertentu. Sementara menurut (Tandelilin, 2010:4), menyatakan bahwa investasi adalah komitmen atas sejumlah dana atau sumberdaya lainnya yang dilakukan pada saat ini, dengan tujuan memperoleh keuntungan di masa datang.

Umumnya investasi dibedakan menjadi dua, yaitu: investasi pada financial assets dan investasi pada real assets. Investasi pada financial assets dilakukan di pasar uang, misalnya berupa sertifikat deposito, commercial paper, surat berharga pasar uang, dan lainnya. Jika itu dilakukan di pasar modal, investasi dapat berupa saham, obligasi, waran, opsi dan lainnya. Sedangkan investasi padareal assets diwujudkan dalam bentuk pembelian aset produktif, pendirian pabrik, pembukaan pertambangan, pembukaan perkebunan dan lainnya.

Seorang investor yang menanamkan modalnya pada suatu perusahaan tentu mengharapkan keuntungan yang diperoleh dari investasi yang dilakukannya. Keuntungan yang dapat diterima oleh investor ada dua yaitu dividen dan capital gain. Dividen adalah laba ditahan perusahaan yang dibagikan kepada pemegang saham. Capital gain adalah nilai keuntungan ketika aset yang dijadikan investasi telah dijual. Menurut (Halim, 2015:135) dividen akan dipergunakan investor 
sebagai alat penduga mengenai prestasi perusahaan dimasa mendatang, dividen menyampaikan pengharapan-pengharapan manajemen mengenai masa depan. Kemudian menurut Halim (2015:135) kebijakan dividen adalah penentuan tentang berapa besarnya laba yang diperoleh dalam suatu periode akan dibagian kepada pemegang saham dalam bentuk dividen, dan akan ditahan dalam perusahaan dalam bentuk laba ditahan.

Ada beberapa teori yang berhubungan dengan dividen dan nilai perusahaan. Menurut teori dividen tidak relevan (Irrelevancy Theory) dari Modigliani dan Miller (MM), nilai perusahaan ditentukan oleh laba bersihsebelum pajak (earnings before interest and tax) dan kelas resiko perusahaan. Nilai perusahaan tidak ditentukan oleh persentaselaba yang dibagikan kepada pemilik saham dalam bentuk dividen. Sedangkan, teori dividen yang relevan (The Bird In The Hand Theory) ditemukan oleh Gordon dan Lintner yaitu tentang return investasi saham yang berupa dividen dan capital gain. Dividen dinyatakan lebih memiliki kepastian daripada capital gain. Investor lebih merasa aman untukmemperoleh pendapatan berupa pembayaran dividen daripada menunggu capital gain. Teori berikutnya adalah Dividend Signalling Theory, yang menyatakan bahwa pengumuman pembayaran dividen oleh manajemen perusahaan adalah sinyal bagi investor. Manajemen ingin menunjukkan bahwa mereka mampu untuk memenuhi pembayaran dividen kepada pemegang saham, informasi mengenai kondisi keuangan yang sehat menandakan bahwa perusahaan memiliki prospek yang bagus dimasa yang akan datang. Menurut teori ini dividen adalah salah satu cara mengurangi asimetri informasi atau ketidakseimbangan informasi antara pihak manajemen dan pemegang saham.

Dividend payout ratio menentukan besarnya dividen yang diterima oleh pemegang saham dan besarnya dividen ini secara positif dapat mempengaruhi harga saham terutama pada pasar yang didominasi oleh investor yang mempunyai strategi mengejar dividen sebagai target yang utama. Dengan demikan, semakin tinggi dividend payout ratio maka akan semakin tinggi pula Price Earnings Ratio. Seperti yang ditemukan dalam penelitian. Shamsuddin \& Hillier (2004), Price Earnings Ratio meningkat sesuai dengan peningkatan dividend payout ratio. Juga, Esana, (2017:206), dividen memiliki pengaruh signifikan terhadap nilai perusahaan.

Bealih dari dividen, hutang perusahaan juga dipercaya dapat mempengaruhi Price Earnings Ratio. Kebijakan hutang merupakan kebijakan yang diambil oleh pihak manajemen dalam rangka memperoleh sumber pendanaan dari pihak ketiga untuk membiayai operasional perusahaan. Menurut Harmono \& Si (2009) keputusan pendanaan oleh manajemen akan berpengaruh pada penelitian perusahaan yang terefleksi pada harga saham. Pecking order theory menyatakan bahwa manajer lebih menyukai pendanaan internal daripada pendanaan eksternal. Jika perusahaan membutuhkan pendanaan dari luar, manajer cenderung memilih surat berharga yang paling aman, seperti hutang. Perusahaan dapat menumpuk kas untuk menghindari pendanaan dari luar perusahaan. Penelitian yang berhubungan dengan hutang dan PER yaitu penelitian dari Endang et al. (2020). Mereka menemukan bahwa semakin tinggi penggunaan leverage dapat menurunkan nilai perusahaan.

Earnings growth juga dipercaya mempengaruhi Price Earning Ratio. Jones (2007) menyatakan bahwa pertumbuhan laba (earnings growth) merupakan prospek earnings perusahaan di masa depan yang bagus, sehingga investor yakin untuk menanamkan modal, yang kemudian akan berpengaruh terhadap tingginya harga saham perusahaan. Semakin tinggi Earnings growth maka nilai Price Earnings ratio perusahaan juga akan semakin tinggi, Sama pada penelitian dari Ananda (2018), growth opportunity berpengaruh positif dan signifikan terhadap nilai perusahaan.

Investor tertarik pada pertumbuhan perusahaan karena memberikan aspek positif dalam arti bahwa dengan adanya pertumbuhan perusahaan merupakan tanda bahwa 
perusahaan memiliki prospek yang menguntungkan di masa depan.

\section{Nilai Perusahaan}

Nilai perusahaan adalah persepsiinvestor terhadap tingkat keberhasilan perusahaan yang sering dikaitkan dengan hargasaham. Menurut Harmono \& Si (2009) nilai perusahaan adalah performa perusahaan yang dilihat daro harga saham yang dibentuk oleh demand dan supply pasar modal merepresentasikan penilaian publik terhadapperforma perusahaan.

Perusahaan perlu memberikan petunjuk mengenai prospek nilai perusahaan dimasa mendatang kepada investor yaitu dengan signalling theory. Brigham dan Houston (2011:184) menyatakan bahwa teori sinyal adalah suatu tindakan yang diambil oleh manajemen perusahaan yang memberikan petunjuk bagi investor tentang bagaimana manajemen memandang prospek perusahaan.

Nilai perusahaan dapat diukur dengan menggunakan Price Earnings Ratio (PER). PER mengukur bagaimana investor melihat prospek pertumbuhan perusahaan dimasa akan datang yang dapat dilihat dari harga sahamyang dibayar untuk laba saham yang didapatkan (Sudana, 2011:23). PER berfungsi untuk menilai kewajaran harga saham suatu perusahaan. PER digunakan perhitungan laba per saham (Earnings Per Share).

Metode penilaian saham berdasarkan analisis fundamental dikenal juga pendekatan Price Earnings Ratio (PER). Pendekatan ini merupakan pendekatan yang lebih populer dipakai dikalangan analis saham dan para praktisi. Dalam pendekatan PER atau disebut juga pendekatan multiplier, investor akan menghitung berapa kali (multiplier) nilai earnings yang tercermin dalam harga suatu saham. Dengan kata lain, PER menggambarkan rasio atau perbandinganantara harga saham terhadap earnings perusahaan. Rumus untuk menghitung PER suatu saham adalah dengan membagi harga saham perusahaan terhadap earnings per lembar saham.
Beberapa penelitian terkait dengan faktor-faktor penentu PER adalah sebagai berikut. Itemgenova and Sikveland (2020) melakukan penelitian dengan menguji penentu dari Price Earnings Ratio pada industry aquaculture di Norwegia. Hasil penelitiannya menunjukkan bahwa Variabel Dividend Payout Ratio (DPR) dan Price to Book Value (PB) berpengaruh positif terhadap Price Earnings Ratio (PER). Variabel Return on Equity (ROE) berpengaruh negatif terhadap Price Earnings Ratio (PER). Expected Return $(\mathrm{E}(\mathrm{R}))$, Leverage

(LEV), Changes in The Salmon Price (Rfish), Changes in Exchange Rate of NOK/USD and NOK/EUR (Rnokeur dan Rnokusd) tidak berpengaruh terhadap Price Earnings Ratio (PER).

Nawangwulan A, Sudjana, and Wi Endang, (2018) menguji harga saham dari sisi kewajarannya dengan menggunakan analisis fundamental Price Earnings Ratio sebagai tolak ukur pengambilan keputusan investasi pada Perusahaan Industri Barang Konsumsi di Bursa Efek Indonesia pada 2013-2016. Hasil penelitian ini menunjukkan bahwa Variabel Return On Equity (ROE), Earnign Per Share (EPS) Dividend Payout Ratio (DPR), dan Earnings Growth (EG) secara simultan berpengaruh signifikan terhadap PER sebesar 60, 1\%. Variabel Return on Equity (ROE) berpengaruh signifikan terhadap Price Earnings Ratio (PER). Earnings Per Share (EPS) tidak berpengaruh terhadap Price Earnings Ratio (PER). Dividend Payout Ratio (DPR) berpengaruh signifikan terhadap Price Earnings Ratio (PER). Earnings Growth (EG) tidak berpengaruh terhadap Price Earnings Ratio (PER).

$\mathrm{Hu}$ and Koshoev (2017) menguji faktorfaktor yang mempengaruhi Price Earnings Ratio di Chinese Stock Market pada tahun 1990-2016.

Mereka menggunakan Price Earnings Ratio sebagai variabel dependen, sedangkan beta and debt ratio, growth rate, return on equity, firm size dan dividend payout ratio sebagai variabel independen. Hasil dari penelitian ini adalah semua variabel kecuali 
beta memiliki pengaruh positif terhadap Price Earnings Ratio.

Rahma and Djazuli (2014) menganalisis variabel fundamental yang berpengaruh terhadap Price Earnings Ratio sebagai dasar penilaian saham pada perusahaan automotive and allied yang terdaftar di bursa efek indonesia. Sampel penelitian ini adalah sampel sensus sehingga diperoleh 6 (enam) perusahaan selama periode 2007-2011. Hasil penelitian ini menunjukkan bahwa Price Earnings Ratio dipengaruhi tidak secara tidak signifikan oleh Return on Equity, Debt to Equity Ratio, Earnings Growth, Earnings per Share, Dividend Payout Ratio, Price to Book Value.

\section{Hipotesis Penelitian}

Dari penjelasan kajian Pustaka yang terkait dengan pengaruh Dividend PayoutRatio Earnings Growth Ratio, Debt to Asset Ratio, dan Dividend Per Share terhadap Price Earnings Ratio, maka hipotesis disini sebagai berikut:

\section{Hipotesis 1 : Dividend Payout Ratio Earnings Growth Ratio, Debt to Asset Ratio, dan Dividend Per Share berpengaruh signifikan terhadap Price Earnings Ratio.}

Hipotesis 2: Dividend Payout Ratio berpengaruh signifikan terhadap Price Earnings Ratio.

\section{Hipotesis 3: Earnings Growth Ratio berpengaruh signifikan terhadap Price Earnings Ratio.}

Hipotesis 4 : Debt to Asset Ratio berpengaruh signifikan terhadap Price Earnings Ratio.

Hipotesis 5 : Dividend Per Share berpengaruh signifikan terhadap Price Earnings Ratio.

\section{METODE PENELITIAN}

Penelitian ini bertujuan untuk mengidentifikasi faktor-faktor penentu Price Earnings Ratio (PER) pada perusahaan yang terdaftar di Indeks LQ45 Bursa Efek
Indonesia periode 2016-2018. Jenis penelitian ini adalah explanatory research (penelitian penjelasan) dengan menggunakan data sekunder. Pendekatan yang digunakan dalam penelitian ini adalah pendekatan kuantitatif.

\section{Populasi dan Kriteria Pemilihan Sampel}

Populasi dalam penelitian ini adalah semua perusahan yang terdaftar di Indek LQ45 pada periode 2016-2018 sebanyak 59 perusahaan. Dengan menggunakan teknik purposive sampling, penelitian ini memperoleh sampel penelitian sebanyak 35 perusahaan. Penelitian ini menyeleksi sampel perusahaan yang secara konsisten melakukan pembagian dividen per akhir tahun, menggunakan perusahaan yang mempunyai total asset positif, dan mengeluarkan jenis perusahaan non-bank dari sampel penelitian.

\section{Definisi Operasional Variabel}

Berikut ini adalah variabel-variabel yang digunakan dalam penelitian ini beserta penjelasan definisinya.

1) Variabel Bebas / Independen (X)

a. Dividend Payout Ratio $\left(\mathrm{X}_{1}\right)$

Dividend Payout Ratio (DPR) merupakan rasio pasar yang menunjukkan presentase dari pendapatan yang dibayarkan kepada pemegang saham sebagai cash dividend. Sehingga penelitian ini dalam menghitung DPR mengikuti pengukuran dari Syamsuddin (2009:75) yaitu dividend per share dibagi dengan

Earnings per share

b. Earnings Growth Ratio $\left(\mathrm{X}_{2}\right)$

Earnings growth merupakan tingkat pertumbuhan laba per lembar saham setiap periode. Mengikuti Damodaran (1996), perhitungan Earnings growth yaitu earnings per share tahun sekarang dikurangi earnings per share tahun sebelum dibagi denganeEarnings per share tahun sebelum. 
c. Debt to Asset Ratio $\left(\mathrm{X}_{3}\right)$ Debt to Asset Ratio (DAR) merupakan rasio utang yang digunakan untuk mengukur perbandingan antara utang dengan total aktiva. DAR dalam penelitian ini dihitung dengan total debt dibagi dengan total asset (Munawir 2010).

d. Dividend Per Share $\left(\mathrm{X}_{4}\right)$ Dividend Per Share (DPS) merupakan laba bersih perusahaan yang dapat dibagikan kepada pemegang saham dalam bentuk dividen. Perhitungan DPS dalam penelitian ini adalah dividen yang dibayarkan dibagi dengan jumlah lembar sahan yang beredar (Tandelilin, 2010:384).

2) Variabel Terikat/Dependen (Y)

Variabel terikat yang digunakan dalam penelitian ini adalah Price Earnings Ratio (PER). PER menunjukkan besarnya harga yang harus dikeluarkan investor untuk mendapatkan earnings perusahaan. PER mencerminkan ekspektasi investor terhadap earnings yang mungkin akan dihasilkan perusahaan dimasa yang akan datang. Semakin kecil nilai PER maka dinilai semakin tinggi. PER dalam penelitian ini dihitung dengan harga saham dibagi dengan EPS (Tandelilin, 2010:320).

\section{Analisis Data}

Tujuan dari penelitian ini adalah untuk mengetahui variabel penjelas manakah yang mempengaruhi PER. Adapun analisis data yang digunakan dalam penelitian ini bersifat kuantitatif yang berupa data panel dengan teknik analisis regresi linear berganda (Winarno, 2017). Pertama kali, penelitian ini melakukan analisis statistik deskriptif kemuadian analisis regresi linier berganda. Regresi linier berganda yang dilakukan pada penelitian ini adalah dengan menggunakan pendekatan Ordinary Least Squares (OLS) dengan tahapan: 1) Estimasi Model Regresi Linier Berganda, 2) Pengujian Asumsi Klasik,
3) Uji Kelayakan Model (Goodness of Fit Model), 4) Intepretasi Model Regresi Linier Berganda. Berikut model regresi dalam penelitian ini.

$$
\begin{aligned}
\mathrm{PER}=\alpha & +\beta_{1} \mathrm{DPR}+\beta_{2} \mathrm{EGR}+\beta_{3} \mathrm{DAR}+\beta_{4} \mathrm{DPS} \\
& +\varepsilon
\end{aligned}
$$

Dimana :

$$
\begin{array}{ll}
\text { PER } & =\text { Price Earnings Ratio } \\
\alpha & =\text { Intercept } \\
\text { DPR } & =\text { Dividend Payout Ratio } \\
\text { EGR } & =\text { Earnings Growth Ratio } \\
\text { DAR } & =\text { Debt to Asset Ratio } \\
\text { DPS } & =\text { Dividend Per Share } \\
\varepsilon \quad & =\text { Standard error } \\
\beta_{1}, \beta_{2}, \beta_{3}, \beta_{4}=\text { Koefisien variabel bebas }
\end{array}
$$

\section{HASIL PENELITIAN DAN PEMBAHASAN}

\section{Analisis Statistik Deskriptif}

Berikut adalah penyajian statistik deskriptif dari variabel penelitian yang dapat dilihat pada Tabel 1 berikut :

Tabel 1 Statistik Deskritif

\begin{tabular}{|l|c|c|c|c|c|}
\hline & N & Min. & Max. & Mean & $\begin{array}{c}\text { Std. } \\
\text { Dev. }\end{array}$ \\
\hline DPR & 105 & 4.540 & 176.680 & 39.536 & 29.104 \\
\hline EGR & 105 & -89.050 & 944.240 & 24.085 & 103.476 \\
\hline DAR & 105 & 0.160 & 0.930 & 0.466 & 0.180 \\
\hline DPS & 105 & 1.300 & & 257.020 & 512.336 \\
\hline PER & 105 & 1.270 & 196.530 & 20.579 & 23.708 \\
\hline
\end{tabular}

Sumber: Data diolah, 2020

Variabel Dividend Payout Ratio (DPR) memiliki nilai terendah sebesar 4,54 dan nilai tertinggi sebesar 176,68 , nilai rata - rata sebesar 39,536 dengan standar deviasi sebesar 29,104. Earnings Growth Ratio (EGR) yang memiliki nilai terendah sebesar $-89,050$ dan nilai tertinggi sebesar 944,240 , nilai rata - rata sebesar 24,085 dengan standar deviasi sebesar 103,476. Walaupun nilai maksimum EGR tinggi, namun nilai rata-ratanya cukup kecil. Hal ini menunjukkan pendapatan perusahaan 
belum menunjukkan pertumbuhan yang besar disetiap tahunnya. Dividend Per Share (DPR) memiliki nilai terendah sebesar 1,3 dan nilai tertinggi sebesar 2600, nilai rata - rata sebesar 257,020 dengan standar deviasi sebesar 512,336. Rentang nilai minimum dan maksimum dari DPS ini sangat besar. Price Earnings Ratio (PER) memiliki nilai terendah sebesar 1,27 dan nilai tertinggi sebesar 196,530, nilai rata - rata sebesar 20,579 dengan standar deviasi sebesar 23,708. Tren nilai rasio yang sangat tajam ditunjukkan oleh hampir semua rasio dalam penelitian kecuali Debt to Asset Ratio (DAR) yang memiliki nilai terendah sebesar 0,160 dan nilai tertinggi sebesar 0,930, nilai rata - rata sebesar 0,466 dengan standar deviasi sebesar 0,180. Hal ini menunjukkan bahwa rasio-rasio perusahaan LQ45 sebagai rasio-rasio penentu PER sangatlah bervariasi.

\section{Analisis Regresi Linear Berganda}

Untuk menguji factor-faktor penentu Price Earnings Ratio (PER), penelitian ini menggunakan analisis regresi linier berganda dengan pendekatan Ordinary Least Squares (OLS) dengan tahapan: 1) Estimasi Model Regresi Linier Berganda, 2) Pengujian Asumsi Klasik, 3) Uji Kelayakan Model (Goodness of Fit Model), 4) Intepretasi Model Regresi Linier Berganda.

\section{1) Estimasi Model Regresi Linier Berganda}

Model yang tepat dalam penelitian ini memerlukan uji chow dan uji hausman.

Adapun hasil uji chow pada tabel 2 menunjukkan metode estimasi terbaik antara common effect dan fixed effect adalah fixed effect. Hal ini karena nilai probabilitas 0,000 kurang dari 0,05 atau menolak $\mathrm{H}_{0}$.

\section{Tabel 2 Hasil Uji Chow}

Effects Test Statistic d.f. Prob.

Cross-section F $5.295(34,66) 0.000$

Cross-section

Chi-square

138.15334 .0000 .000
Selanjutnya hasil uji hausman pada tabel 3 mencerminkan metode estimasi terbaik antara fixed effect dan random effect model. Hal ini karena nilai probabilitas 0,000 yang berarti kurang dari

0,05, maka menolak $\mathrm{H}_{0}$. Hal ini menunjukkan bahwa fixed effect adalah model yang terpilih.

Tabel 3 Hasil Uji Hausman

\begin{tabular}{llll}
\hline & & & \\
& $\begin{array}{l}\text { Chi-Sq. } \\
\text { Sest Summary }\end{array}$ & Chi-Sq. & \\
& d.f. & Prob. \\
\hline \hline $\begin{array}{l}\text { Cross-section } \\
\text { random }\end{array}$ & 28.614 & 4.000 & 0.000 \\
\hline \hline
\end{tabular}

Sumber : Data diolah, 2020

Uji Hausman memutuskan metode estimasi terbaik yang digunakan dalam penelitian ini dengan Model fixed effect. Dari hasil kedua uji diatas, maka dapat disimpulkan model terbaik dari estimasi model regresi adalah Model fixed effect

\section{2) Pengujian Asumsi Klasik a. \\ Normalitas}

Tes Normalitas dilakukan untuk mengetahui apakah nilai residual tersebar normal atau tidak. Sistematika uji ini adalah dengan melakukan uji jarque bera.

Berikut hipotesisnya:

$\mathrm{H}_{0}$ : Residual tersebar normal

$\mathrm{H}_{1}$ : Residual tidak tersebar normal Apabila

nilai signifikansi ( $p$-value) lebi

dari 0,05 maka $\mathrm{H}_{0}$ diterima. Ini berarti tes normalitas terpenuhi. Hasil tes normalitasdapat didiskripsikan pada Gambar 1.

Sumber : Data diolah, 2020 


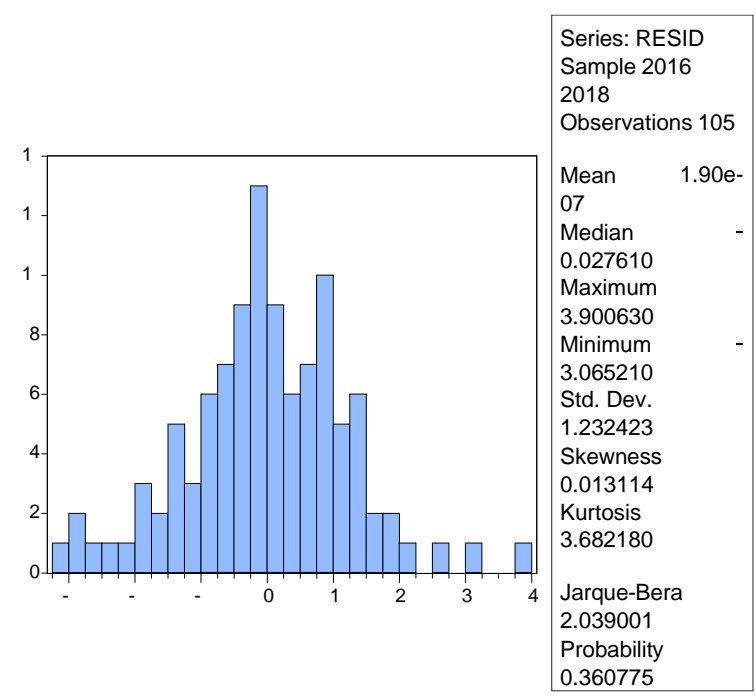

Gambar 1 Normalitas

Sumber: Data diolah, 2020

Melihat dari hasil histogram diatas nilai probabilitas yang diperoleh yaitu 0,360775 , yang berarti nilai signifikan yang dihasilkan lebih dari 0,05. Hal tersebut dapat disimpulkan bahwa, data dalam penelitian ini berdistribusi normal.

\section{b. Multikolinieritas}

Tes Multikolinieritas ini dilakukan untuk mengetahui bahwa tidak terjadi hubungan yang sangat kuat atau tidak terjadi hubungan linier yang sempurna. Hal ini berarti juga antar variabel bebas tidak saling berkaitan. Adapun, langkah pengujiannya yaitu membandingkan nilai korelasi yang didapat dari perhitungan regresi panel. Jika nilai korelasi antar variabel $<0,8$ maka tidak terjadi multikolinearitas. Hasil uji multikolinieritas dapat dilihat pada Tabel 4.

Tabel 4. Multikolinieritas

\begin{tabular}{lcccc}
\hline & DPR & EGR & DAR & DPS \\
\hline DPR & 1.000 & 0.011 & -0.287 & 0.618 \\
EGR & 0.011 & 1.000 & 0.128 & 0.062 \\
DAR & -0.287 & 0.128 & 1.000 & -0.128 \\
DPS & 0.618 & 0.062 & -0.128 & 1.000 \\
\hline
\end{tabular}

Sumber: Data diolah penulis, 2020

Tabel 5 menunjukkan hasil pengujian dari masing-masing variabel bebas memiliki korelasi lebih kecil dari 0,8 . Sehingga, hal ini tidak tterdapat multikolinearitas antar variabel independen.

\section{c. Heterokedastisitas}

Tes heterokedastisitas diperlukan untuk mengetahui apakah terjadi ketidaksamaan nilai simpangan residual akibat besar kecilnya nilai salah satu variabel bebas. Dengan kata lain, adanya perbedaaan nilai ragam dengansemakin meningkatnya nilai variabel bebas. Prosedur ini dilakukan dengan tes Glejser. Berikut hipotesisnya:

$$
\begin{aligned}
& \mathrm{H}_{0} \text { : Ragam sisaan homogen } \\
& \mathrm{H}_{1} \text { : Ragam sisaan tidak homogen }
\end{aligned}
$$

Hasil uji heterokedastisitas dapat dilihat pada tabel 5.

\section{Tabel 5 Heteroskedastisistas}

Dependent Variable: ABSRES

Method: Panel Least Squares

\begin{tabular}{|c|c|c|c|c|}
\hline Variable & Coefficient & Std. Error & t-Statistic & Prob. \\
\hline $\mathrm{C}$ & 1.102 & 0.248 & 4.446 & 0.000 \\
\hline $\mathrm{X} 1$ & -0.055 & 0.042 & -1.302 & 0.196 \\
\hline $\mathrm{X} 2$ & -0.007 & 0.016 & -0.464 & 0.644 \\
\hline $\mathrm{X} 3$ & 0.102 & 0.056 & 1.809 & 0.073 \\
\hline X4 & -0.010 & 0.017 & -0.624 & 0.534 \\
\hline
\end{tabular}

Sample: 20162018

Sumber: Data diolah, 2020

Dengan melihat Tabel 5, berikut hasil uji heterokedastisitas untuk masing-masing variabel :

a) Nilai Prob. untuk DPR adalah 0,196

b) Nilai Prob.untuk EGR adalah 0,644

c) Nilai Prob.untuk DAR adalah 0,073

d) Nilai Prob.untuk DPS adalah 0,534

Dari hasil pengujian tersebut didapat bahwa nilai prob seluruh variabel adalah $>\alpha(\alpha$ 
$=0,05)$. Ini berarti sisaan mempunyai ragam homogen (konstan) atau tidak terdapat gejala heterokedastisitas.

\section{d. Autokorelasi}

Tes autokorelasi adalah uji untuk mengetahui korelasi antara sisaan secara time series atau cross-section. Dalam regresi, model klasik mengasumsikan bahwa tidak terdapat autokorelasi dalam sisaan $\left(\varepsilon_{i}\right)$. Jadi, model tersebut memperkirakan bahwa unsur sisaan yang terkait observasi tidak dipengaruhi oleh sisaan observasi lain.

Tes ini menggunakan tes Durbin-Watson. Berikut hipotesisnya.

$H_{0}: \rho=0$ (tidak terdapat autokorelasi antar sisaan)

$H_{1}: \mathrm{r}^{1} 0$ (terdapat autokorelasi antar sisaan)

Sedangkan, statistik DurbinWatson menggunakan persamaan statistik d, yaitu:

$$
d=\underline{a ̊}\left(e a_{t}-e_{2 t-1}\right)_{2}
$$

$e$

Banyak observasi pada pembilangstatistik $\mathrm{d}$ adalah $\mathrm{n}-1$ karena satu observasi hilang dalam mendapatkan pembedaan yang berurutan. Sistematika tes sebagai berikut:

1. Penggunaan metode kuadrat terkecil biasa, hitung koefisien regresi, kemudian tentukan $\mathrm{e}_{\mathrm{i}}$.

2. Perhitungan statistik d

3. Penentuan nilai-nilai kritis $d_{L}$ dan $d_{U}$ berdasarkan banyaknya observasi dan peubah penjelas

4. Penerapan kaidah keputusan: a. Jika $\mathrm{d}<\mathrm{d}_{\mathrm{L}}$ atau $\mathrm{d}>\left(4-\mathrm{d}_{\mathrm{L}}\right)$, maka $\mathrm{H}_{0}$ ditolak, yang berarti terdapat autokorelasi terhadap sisaan.

b. Jika $d_{U}<d<\left(4-d_{U}\right)$, maka $H_{0}$ diterima, berarti tidak terdapat auotokorelasi antar sisaan.

c. Jika d $_{\mathrm{L}}<\mathrm{d}<\mathrm{d}_{\mathrm{U}}$ atau $\left(4-\mathrm{d}_{\mathrm{U}}\right)<\mathrm{d}$ $<\left(4-\mathrm{d}_{\mathrm{L}}\right)$, maka tes DurbinWatson tidak menghasilkan kesimpulan yang pasti (inconclusive).

Untuk nilai-nilai ini, tidak dapat (pada suatu tingkat signifikansi tertentu) disimpulkan ada tidaknya autokorelasi di antara faktorfaktor gangguan.

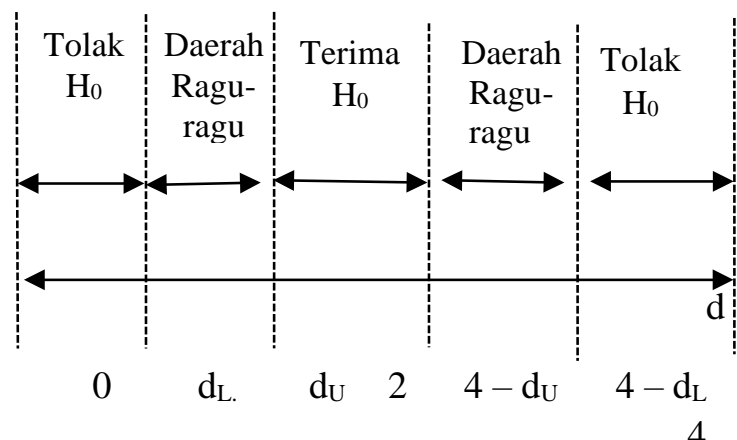

Dimana:

$\mathrm{d}_{\mathrm{U}}=$ Durbin-Watson Upper (batas atas dari tabel Durbin-Watson)

$$
\begin{aligned}
\mathrm{d}_{\mathrm{L}}= & \text { Durbin-Watson Lower (batas bawah } \\
& \text { dari tabel Durbin-Watson) }
\end{aligned}
$$

Dari tabel Durbin-Watson untuk $\mathrm{n}=105$ dan $\mathrm{k}=4$ (adalah banyaknya variabel bebas) diketahui nilai du sebesar 1.762 dan 4-du sebesar 2.238. Hasil tes autokorelasi dapat dilihat pada Tabel 6 .

Tabel 6 Hasil Tes Autokorelasi

\begin{tabular}{|c|c|}
\hline Model & Durbin-Watson \\
\hline FEM & 1,903 \\
\hline
\end{tabular}

Sumber: Data diolah, 2020

Dari Tabel 4.7 diketahui nilai tes Durbin Watson sebesar 1,903 yang terletak antara 
1.762 dan 2.238, maka dapat disimpulkan bahwa asumsi tidak terdapat autokorelasi.

\section{3) Uji Kelayakan Model (Goodness of Fit Model)}

Selanjutnya untuk menjawab hipotesis penelitian ini yang terkait dengan dampak Dividend Payout Ratio (DPR), Earnings Growth Ratio (EGR), Debt to Asset Ratio (DAR), dan Dividend Per Share (DPS) terhadap Price Earnings Ratio (PER), berikut
$\mathrm{PER}=6,100+0,912 \mathrm{DPR}+0,027 \mathrm{EGR}-$ 0,045

DAR - 0,842 DPS

- Koefisien Dividend Payout Ratio (DPR) adalah 0,912. Ini berarti bahwa Price Earnings Ratio (PER) akan meningkat untuk setiap tambahan Dividend Payout Ratio. Sehingga, apabila Dividend Payout Ratio terjadi peningkatan, Price Earnings Ratio juga akan meningkat sebesar 0,912 satuan dimana variabel yang lainnya dianggap tetap.

- Koefisien Earnings Growth Ratio

Tabel 7. Hasil Regresi Linier Berganda dari Model Fixed Effect

\begin{tabular}{lllll}
\hline Variable & Coefficient & Std. Error & t-Statistic & Prob. \\
\hline & & & & \\
C & 6.100 & 1.368 & 4.460 & 0.000 \\
DPR & 0.912 & 0.163 & 5.602 & 0.000 \\
EGR & 0.027 & 0.037 & 0.713 & 0.478 \\
DAR & -0.045 & 0.522 & -0.087 & 0.931 \\
DPS & -0.842 & 0.110 & -7.644 & 0.000 \\
\hline \hline
\end{tabular}

Effects

Specification

Cross-section fixed (dummy variables)

$\begin{array}{lllr}\text { R-squared } & 0.833 & \text { Mean dependent var } & 5.417 \\ \text { Adjusted R-squared } & 0.736 & \text { S.D. dependent var } & 1.561 \\ \text { S.E. of regression } & 0.801 & \text { Akaike info criterion } & 2.673 \\ \text { Sum squared resid } & 42.377 & \text { Schwarz criterion } & 3.659 \\ \text { Log likelihood } & -101.353 & \text { Hannan-Quinn criter. } & 3.073 \\ \text { F-statistic } & 8.643 & \text { Durbin-Watson stat } & 1.903 \\ \text { Prob(F-statistic) } & 0.000 & & \end{array}$

Sumber: Data diolah, 2020

ini disajikan hasil penelitian. Tabel 7 . menunjukkan hasil regresi linear berganda dari model fixed effect.Berikut ini persamaan regresi yang dihasilkan dan penjelasan hasilnya:
(EGR) adalah 0,027. Ini berarti bahwa Price Earnings Ratio akan meningkat untuk setiap tambahan Earnings Growth Ratio. Sehingga, apabila Earnings Growth Ratio terjadi peningkatan, maka Price

Earnings Ratio akan meningkat sebesar 
0,027 satuan dimana variabel yang lainnya dianggap tetap.

- Koefisien Debt to Asset Ratio (DAR) adalah -0,045. Ini berarti bahwa Price Earnings Ratio akan menurun untuk setiap tambahan Debt to Asset Ratio, Sehingga, apabila Debt to Asset Ratio terjadi peningkatan, maka Price Earnings Ratio akan menurun sebesar 0,045 satuan dimana variabel yang lainnya dianggap tetap.

- Koefisien Dividend Per Share (DPS) adalah -0,842. Ini berarti bahwa Price Earnings Ratio akan menurun untuk setiap tambahan Dividend Per Share. Sehingga, jika Dividend Per Share terjadi peningkatan, maka Price Earnings Ratio akan turun sebesar 0,842 satuan dimana variabel yang lainnya dianggap tetap.

\section{a. Koefisien Determinasi $\left(\mathrm{R}^{2}\right)$}

Untuk mengetahui besar kontribusi variabel bebas (Dividend Payout Ratio $\left(\mathrm{X}_{1}\right)$, Earnings Growth Ratio $\left(\mathrm{X}_{2}\right)$, Debt to Asset Ratio $\left(\mathrm{X}_{3}\right)$, dan Dividend Per Share $\left(\mathrm{X}_{4}\right)$ ) terhadap variabel terikat (Price Earnings Ratio) digunakan nilai adjusted $\mathrm{R}^{2}$. Nilai adjusted $\mathrm{R}^{2}$ (koefisien determinasi) sebesar 0,736 yang berarti bahwa 73,6\% variabel Price Earnings Ratio akan dipengaruhi oleh variabel bebasnya, yaitu Dividend Payout Ratio $\left(\mathrm{X}_{1}\right)$, Earnings Growth Ratio $\left(\mathrm{X}_{2}\right)$, Debt to Asset Ratio $\left(\mathrm{X}_{3}\right)$, dan Dividend Per Share $\left.\left(\mathrm{X}_{4}\right)\right)$. Sedangkan sisanya 26,4\% variabel Price Earnings Ratio akan dipengaruhi oleh variabel-variabel yang lain yang tidak dibahas dalam penelitian ini.

\section{b. Tes Simultan (F)}

Tes $\mathrm{F}$ (model) digunakan untuk mengetahui signifikasi dari model regresi. Apabila hasilnya adalah signfikan, maka $\mathrm{H}_{0}$ ditolak dan $\mathrm{H}_{1}$ diterima dan model regresi yang dinyatakan baik. Begitu pula sebaliknya apabila hasilnya tidak signifikan. Berikut keterangan dari hipotesisnya :

$\mathrm{H}_{0}$ ditolak apabila $\mathrm{F}$ hitung $>\mathrm{F}$ tabel

$\mathrm{H}_{0}$ diterima apabila $\mathrm{F}$ hitung $<\mathrm{F}$ tabel

Berdasarkan Tabel 7, nilai $\mathrm{F}$ hitung sebesar 8,643 dan F tabel sebesar 2,463 ( $\alpha$ $=0,05, \mathrm{db}$ regresi $=4, \mathrm{db}$ residual $=100)$. Karena $\mathrm{F}$ hitung $>\mathrm{F}$ tabel $(8,643>2,463)$ dengan nilai Prob F $(0,000)$ kurang dari $\alpha$ $(0,05)$ maka model regresi adalah baik. Ini dapat diartikan bahwa $\mathrm{H}_{0}$ ditolak dan $\mathrm{H}_{1}$ diterima dimana Dividend Payout Ratio (DPR), Earnings Growth Ratio (EGR), Debt to Asset Ratio (DAR), dan Dividend Per Share (DPS) berpengaruh signifikan terhadap Price Earnings Ratio (PER).

Hasil ini mendukung hipotesis 1 penelitian.

c. Hipotesis Partial (t test/ Parsial)

T-test digunakan untuk mengetahui apakah masing-masing variabel bebas secara parsial mempunyai pengaruh yang signifikan terhadap variabel terikat. Dapat juga dikatakan jika $t$ hitung $>t$ tabel atau $t$ hitung < - t tabel maka hasilnya signifikan dan berarti $\mathrm{H}_{0}$ ditolak dan $\mathrm{H}_{1}$ diterima. Sedangkan jika $t$ hitung $<\mathrm{t}$ tabel atau $-\mathrm{t}$ hitung > -t tabel maka hasilnya tidak signifikan dan berarti $\mathrm{H}_{0}$ diterima dan $\mathrm{H}_{1}$ ditolak.

Berdasarkan Tabel 6 diperoleh hasil sebagai berikut :

1) T-test antara DPR dengan PER menunjukkan $\mathrm{t}$ hitung $=5,602$. Sedangkan $\mathrm{t}$ tabel $(\alpha=0,05 ; \mathrm{db}$ residual $=100)$ adalah sebesar 1,984. Karena $\mathrm{t}$ hitung $>\mathrm{t}$ tabel yaitu 5,602 > 1,984 atau Prob. t $(0,000)<$ $\alpha=0,05$ maka pengaruh DPR terhadap PER adalah signifikan. Hal ini berarti $\mathrm{H}_{0}$ ditolak, sehingga dapat disimpulkan bahwa Price Earnings Ratio dipengaruhi secara signifikan oleh Dividend Payout Ratio atau dengan meningkatkan Dividend Payout Ratio maka Price 
Earnings Ratio akan mengalami peningkatan secara nyata.

2) T-test antara EGR dengan PER menunjukkan thitung $=0,713$. Sedangkan $\mathrm{t}$ tabel $(\alpha=0,05 ; \mathrm{db}$ residual $=100)$ adalah sebesar 1,984 . Karena $\mathrm{t}$ hitung $<\mathrm{t}$ tabel yaitu $0,713<1,984$ atau Prob. $t(0,478)>$ $\alpha=0,05$ maka pengaruh EGR terhadap PER adalah tidak signifikan pada alpha $5 \%$. Hal ini berarti $\mathrm{H}_{0}$ diterima, sehingga dapat disimpulkan bahwa Price Earnings Ratio dipengaruhi secara tidak signifikan oleh Earnings Growth Ratio.

3) T-test antara DAR dengan PER menghasilkan t hitung sebesar $-0,087$ dan $\mathrm{t}$ tabel sebesar 1,984 $(\alpha=0,05$; db residual $=100$ ). Ini tampak bahwa t hitung lebih kecil $\mathrm{t}$ tabel dengan Prob. $\mathrm{t}(0,931)$ kurang dari $\alpha(0,05)$. Sehingga, itu terdapat pengaruh tidak signifikan Debt to Asset Ratio (DAR) terhadap Price Earnings Ratio (PER) ( $\mathrm{H}_{0}$ diterima).

4) T-test antara DPS dan PER menghasilkan t hitung $=7,644$. Sedangt tabel $(\alpha=0,05$; $\mathrm{db}$ residual $=100)$ adalah sebesar 1,984 . Dengan $t$ hitung $>\mathrm{t}$ tabel yaitu 7,644 > 1,984 atau Prob.t $(0,000)<\alpha=0,05$ maka pengaruh DPS terhadap PER adalah signifikan pada alpha 5\%. Hal ini menghasilkan $\mathrm{H}_{0}$ ditolak yang berarti Price Earnings Ratio dipengaruhi secara signifikan oleh Dividend Per Share.

Secara keseluruhan dapat disimpulkan bahwa variabel Dividend Payout Ratio, Earnings Growth Ratio, Debt to Asset Ratio, dan Dividend Per Share mempunyai pengaruh terhadap Price Earnings Ratio secara simultan dan parsial. Ini juga dapat diketahui bahwa keempat variabel bebas tersebut yang paling dominan pengaruhnya terhadap Price Earnings Ratio adalah Dividend Payout Ratio karena memiliki nilai koefisien beta paling besar dan signifikan (0,912, sig. 0.000).

\section{Pembahasan}

1) Pengaruh Dividend Payout Ratio (DPR) terhadap Price Earnings Ratio (PER)

Hasil regresi di Tabel 7 mendiskripsikan bahwa t hitung senilai 5,602 dengan prob. $\mathrm{t}$ senilai 0,000 dan $\mathrm{t}$ tabel senilai 1,984. Sedangkan, nilai probabilitas $t$ adalah 0,000 dimana itu lebih kecil dari alpha $(0,05)$ yang digunakan. Sehingga, ini dapat disimpulkan dividend payout ratio mempunyai pengaruh yang signifikan terhadap Price Earnings Ratio. Hasil ini mendukung hipotesis 2penelitian.

Pengaruh dividend payout ratio terhadap Price Earnings Ratio memberikan efek peningkatan, dengankata lain dividend payout ratio telah memberikan kontribusi terhadap peningkatan Price Earnings Ratio perusahaan di Indonesia secara signifikan. Hasil ini sejalan dengan kesimpulan pada penelitian yang telah dilakukan sebelumnya oleh Shamsuddin and Hillier (2004) yang hasil penelitiannya menyatakan bahwa Price Earnings Ratio meningkat sesuai dengan peningkatan dividend payout ratio dan penelitian Nawangwulan A, Sudjana, and Wi Endang (2018) yang mengatakan bahwa dividend payout ratio berpengaruh signifikan terhadap Price Earnings Ratio. Penelitian ini juga mendukung temuan Jones (2007) bahwa semakin tinggi dividend payout ratio maka akan semakin tinggi pula Price Earnings Ratio. Hasil ini juga relevan dengan penelitian yang dilakukan oleh Itemgenova dan Sikveland (2020) yang menemukan adanya hubungan positif antara Price Earnings Ratio dengan dividend payout ratio, yang konsisten dengan teori dividend signaling theory. Teori ini menyatakan bahwa dividend payout ratio yang tinggi saat ini menunjukkan profitabilitas masa depan yang tinggi atas investasi perusahaan. 


\section{2) Pengaruh Earnings Growth Ratio (EGR) terhadap Price Earnings Ratio (PER)}

Pada hasil regresi (Tabel 7) diperoleh nilai t-hitung sebesar 0,713 dengan $\mathrm{t}$ tabel sebesar 1,984. Sedangkan, nilai probabilitas $\mathrm{t}$ sebesar 0,478 dimana ini lebih besar dari alpha $(0,05)$ yang digunakan. Ini berarti Earnings Growth Ratio memiliki pengaruh yang tidak signifikan terhadap Price Earnings Ratio. Hasil ini tidak mendukung hipotesis 3 penelitian.

Pada penelitian ini Earnings growth memiliki pengaruh terhadap Price Earnings Ratio walaupun tidak secara signifikan. Hal tersebut didukung oleh penelitian Rahma dan Djazuli (2014) yang mengatakan bahwa Earnings growth berpengaruh tidak signifikan terhadap Price Earnings Ratio. Jones (2007) menjelaskan bahwa pertumbuhan laba (Earnings growth) menunjukkan prospek Earnings perusahaan di masa depan yang bagus, sehingga investor yakin untuk menanamkan modal, yang kemudian akan berpengaruh terhadap tingginya harga saham perusahaan. Semakin tinggi Earnings growth maka nilai price Earnings ratio perusahaan juga akan semakin tinggi. Hasil ini juga relevan dengan signalling theory yaitu dengan memberikan petunjuk mengenai pertumbuhan laba perusahaan maka dapat menarik investor serta meningkatkan nilai perusahaan. Hasil yang tidak signifikan didalam penelitian ini adalah dimungkinkan karena dividen sebagai salah satu cara mengurangi asimetri informasi atau ketidakseimbangan informasi antara pihak manajemen dan pemegang saham tidak begitu efektif diterapkan di perusahaan Indonesia.

\section{3) Pengaruh Debt to Asset Ratio (DAR) terhadap Price Earnings Ratio (PER)}

Pada hasil regresi (Tabel 7) diperoleh nilai t-hitung sebesar -0,087 dengan t tabel sebesar 1,984. Sedangkan, nilai probabilitas $\mathrm{t}$ sebesar 0,931 dimana ini lebih besar dari alpha $(0,05)$ yang digunakan. Sehingga, ini dapat disimpulkan debt to asset ratio mempunyai pengaruh yang tidak signifikan terhadap Price Earnings Ratio. Hasil ini tidak mendukung hipotesis 4 penelitian.

Pada penelitian ini Price Earnings Ratio dipengaruhi secara tidak signifikan oleh debt to asset ratio Hasil ini sejalan dengan kesimpulan pada penelitian yang telah dilakukan sebelumnya oleh Endang et al. (2020) yaitu semakin tinggi penggunaan leverage dapat menurunkan nilai perusahaan. Hasil ini sesuai dengan pecking order theory dimana manajer lebih menyukai pendanaan internal daripada pendanaan eksternal, yaitu berasal dari laba ditahan dan depresiasi aliran kas, jika dana internal tidak mencukupi perusahaan baru menggunakan dana eksternal misalnya dengan melakukan emisi obligasi yang bisa menjadi signal negatif oleh pasar bahwa perusahaan kekurangan dana sehingga hutang yang tinggi dapat menurunkan nilai perusahaan. Namun, hasil yang tidak signifikan disini bisa jadi karena adanya beberapa pilihan pendanaan internal perusahaan dan ini sangat bervariasi penggunaanya oleh perusahaan di Indonesia. Disamping itu, laba ditahan perusahaan juga tampaknya kurang mampu sebagai alternatif pendanaan perusahaan, mengingat karekteristik investor di perusahaan Indonesia lebih menyukai cash deviden sehingga ini mempengaruhi PER perusahaan.

4) Pengaruh Dividend Per Share (DPS) terhadap Price Earnings Ratio (PER)

Pada hasil regresi (Tabel 7) diperoleh t-hitung senilai $-7,644$ dan $\mathrm{t}$ tabel senilai 1,984. Sedangkan, probabilitas $\mathrm{t}$ senilai 0,000 yang lebih kecil dari alpha $(0,05)$ yang digunakan. Sehingga, ini dapat disimpulkan Dividend Per Share mempunyai pengaruh yang signifikan terhadap Price Earnings Ratio. Hasil ini mendukung hipotesis 5 penelitian 
Pada studi ini Price Earnings Ratio terdampak signifikan oleh dividend per

share. Hasil ini sejalan terhadap penelitian Esana (2017) mengenai deviden memiliki pengaruh signifikan terhadap nilai perusahaan. Hasil ini juga relevan dengan teori yang ditemukan oleh Gordon dan Lintner yaitu the bird in the hand theory, teori ini menyatakan bahwa dividen lebih memiliki kepastian daripada capital gain sehingga Investor lebih merasa amanuntuk memperoleh pendapatan berupa pembayaran dividen daripada menunggu capital gain sehingga dividen dapat mempengaruhi nilai perusahaan.

\section{KESIMPULAN DAN SARAN}

\section{Kesimpulan}

Studi ini dilaksanakan untuk melihat dampak Dividend Payout Ratio, Earnings Growth Ratio, Debt to Asset Ratio, dan Dividend Per Share terhadap Price Earnings Ratio. Variabel penjelas adalah variabel Dividend Payout Ratio, Earnings Growth Ratio, Debt to Asset Ratio, dan Dividend Per Share sedangkan variabel terikat yang digunakan adalah Price Earnings Ratio. Hasil penelitian menunjukkan bahwa Dividend Payout Ratio, Earnings Growth Ratio, Debt to Asset Ratio, dan Dividend Per Share mempunyai pengaruh yang signifikan secara simultan terhadap Price Earnings Ratio.

Sedangkan berdasarkan hasil uji t, Dividend Payout Ratio mempunyai pengaruh signifikan terhadap Price Earnings Ratio, Earnings Growth Ratio mempunyai pengaruh tidak signifikan terhadap Price Earnings Ratio, Debt to Asset Ratio mempunyai pengaruh tidak signifikan terhadap Price Earnings Ratio, Dividend Per Share mempunyai pengaruh signifikan terhadap Price Earnings Ratio. Dividend Per Share mempunyai nilai t-hitung dan koefisien beta yang paling besar. Temuan yang menarik dalam penelitian ini adalah bahwa Dividend Payout Ratio merupakan rasio yang paling dominan dalam menentukan Price Earnings Ratio.

\section{Saran}

Berdasarkan kesimpulan di atas, dapat

dikemukakan beberapa saran yang diharapkan dapat bermanfaat bagi perusahaan maupun bagi pihak-pihak lain. Adapun saran yang diberikan, antara lain:

1) Pihak perusahaan dapat mempertimbangkan Dividend Per Share, dalam rangka meningkatkan Price Earnings Ratio. Mengingat bahwa Dividend Per Share dalam penelitian ini mempunyai pengaruh yang dominan dalam mempengaruhi Price Earnings Ratio sebagai tolak ukur untuk berinvestasi.

2) Penelitian selanjutnya dengan topik yang sama dapat mempertimbangkan penggunaan variabel-variabel lainnya yang mempengaruhi Price Earnings Ratio, mengingat dalam penelitian ini variabel yang digunakan terbatas.

3) Penelitian selanjutnya dapat mempertimbangkan untuk memperluas periode penelitian sehingga mampu menggambarkan tren hasil yang lebih komprehensif.

4) Penelitian selanjutnya dapat mempertimbangkan penggunaan variabel kontrol yang kemungkinan dapat lebih memperkuat hasil penelitian.

\section{DAFTAR PUSTAKA}

Agus, Sartono. 2010. "Manajemen Keuangan Teori Dan Aplikasi Edisi 4.” Yogyakarta: BPFE.

Ananda, Nova Adhitya. 2018. "PENGARUH GROWTH OPPORTUNITY TERHADAP NILAI PERUSAHAAN MELALUI STRUKTUR MODAL (Pada Perusahaan Sektor Property, Real Estate \& Building Construction Yang Terdaftar Di Bursa Efek Indonesia Tahun 20112014)." Jurnal Distribusi 4(2): 1528. 
Brigham, Eugene F dan Joel F. Houston. 2011. Manajemen Keuangan. Edisi Bahasa Indonesia. Jakarta: Salemba Empat.

Damodaran, Aswath. 1996. Corporate Finance. Wiley.

Endang, M G Wi, Suhadak Suhadak, Mohammad Saifi, and Nila Firdausi.

2020. "The Effect of Ownership Structure and Leverage towards Dividend Policy and Corporate Values." JPAS (Journal of Public Administration Studies) 5(1): 1-4.

Esana, Ria. 2017. "Pengaruh Kebijakan Dividen Dan Keputusan Investasi Terhadap Nilai Perusahaan Serta Dampaknya Terhadap Profitabilitas T+1 (Studi Pada Sub Sektor Industri Barang Konsumsi Yang Terdaftar Di BEI Periode 2006-2016)."

Halim, Abdul. 2015. "Analisis Investasi Di Aset Keuangan." Language 12(210p): $24 \mathrm{~cm}$.

Harmono, Dr, and M Si. 2009. "Manajemen Keuangan Berbasis Balance Scorecard." Pendekatan Teori, Kasus dan Riset Bisnis.

Hartono, Jogiyanto. 2017. "Teori Portofolio Dan Analisis Investasi Edisi Kesebelas." Yogyakarta: BPFE.

Hu, John Wei-Shan, and Askar Koshoev. 2017. "Five Factors to Measure $\mathrm{P} / \mathrm{E}$ Ratio in China." International Research Journal of Applied Finance 8(3): 154-62.

Itemgenova, Aigerim, and Marius Sikveland. 2020. "The Determinants of the PriceEarnings Ratio in the Norwegian Aquaculture Industry." Journal of Commodity Markets 17: 100089.

Jones, Charles P. 2007. Investments: Analysis and Management. John Wiley \& Sons.

Munawir, Slamet. 2010. "Analisa Laporan Keuangan Edisi 4.” Yogyakarta: Liberty.

Nawangwulan A, Rery, Nengah Sudjana, and M G Wi Endang. 2018. "KEWAJARAN
HARGA SAHAM MENGGUNAKAN

ANALISIS FUNDAMENTAL PRICE EARNING RASIO (PER) SEBAGAI

DASAR

PENGAMBILAN

KEPUTUSAN INVESTASI (Studi Pada

Perusahaan Subsektor Industri Barang

Konsumsi Yang Listed Di Bursa Efek Indonesia Tahun 2013-2016)." Jurnal Administrasi Bisnis 62(2): 204-13.

Rahma, Erlin Yulia, and Atim Djazuli. 2014.

"Analisis Variabel Fundamental Yang Berpengaruh Terhadap Price Earning Ratio (PER) Sebagai Dasar Penilaian Saham Pada Perusahaan Automotive and Allied Yang Terdaftar Di Bursa Efek Indonesia." Jurnal Aplikasi Manajemen 12(3): 362-72.

Shamsuddin, Abul F M, and John R Hillier. 2004. "Fundamental Determinants of the Australian Price-Earnings Multiple." Pacific-basin finance journal 12(5): 56576.

Sudana, Imade. 2011. "Manajemen Keuangan Perusahaan: Teori \& Praktik."

Sunariyah. 2000. Pengantar Pengetahuan Pasar Modal. UPP Akademi Manajemen Perusahaan YKPN.

Syamsuddin. 2009. Manajemen Keuangan

Perusahaan. Jakarta: PT.

Raja Grafindo Persada.

Tandelilin, Eduardus. 2010. "Portofolio Dan Investasi, Edisi Pertama." Yogyakarta: Kanisius 1(1).

Winarno, Wing Wahyu. 2017. "Analisis Ekonometrika Dan Statistika Dengan Eviews." 